\title{
Marisol's Story: Culture, Family, Self, and The Decision to Get an Abortion
}

Jean Peterman

Follow this and additional works at: https://via.library.depaul.edu/dialogo

Part of the Latin American Languages and Societies Commons

\section{Recommended Citation}

Peterman, Jean (2002) "Marisol's Story: Culture, Family, Self, and The Decision to Get an Abortion," Diálogo: Vol. 6: No. 1, Article 4.

Available at: https://via.library.depaul.edu/dialogo/vol6/iss1/4

This Article is brought to you for free and open access by the Center for Latino Research at Digital Commons@DePaul. It has been accepted for inclusion in Diálogo by an authorized editor of Digital Commons@DePaul. For more information, please contact digitalservices@depaul.edu. 


\section{Marisol's Story: Culture, Family, Self, and The Decision to Get an Abortion}

\section{Cover Page Footnote}

This article is from an earlier iteration of Diálogo which had the subtitle "A Bilingual Journal." The publication is now titled "Diálogo: An Interdisciplinary Studies Journal." 


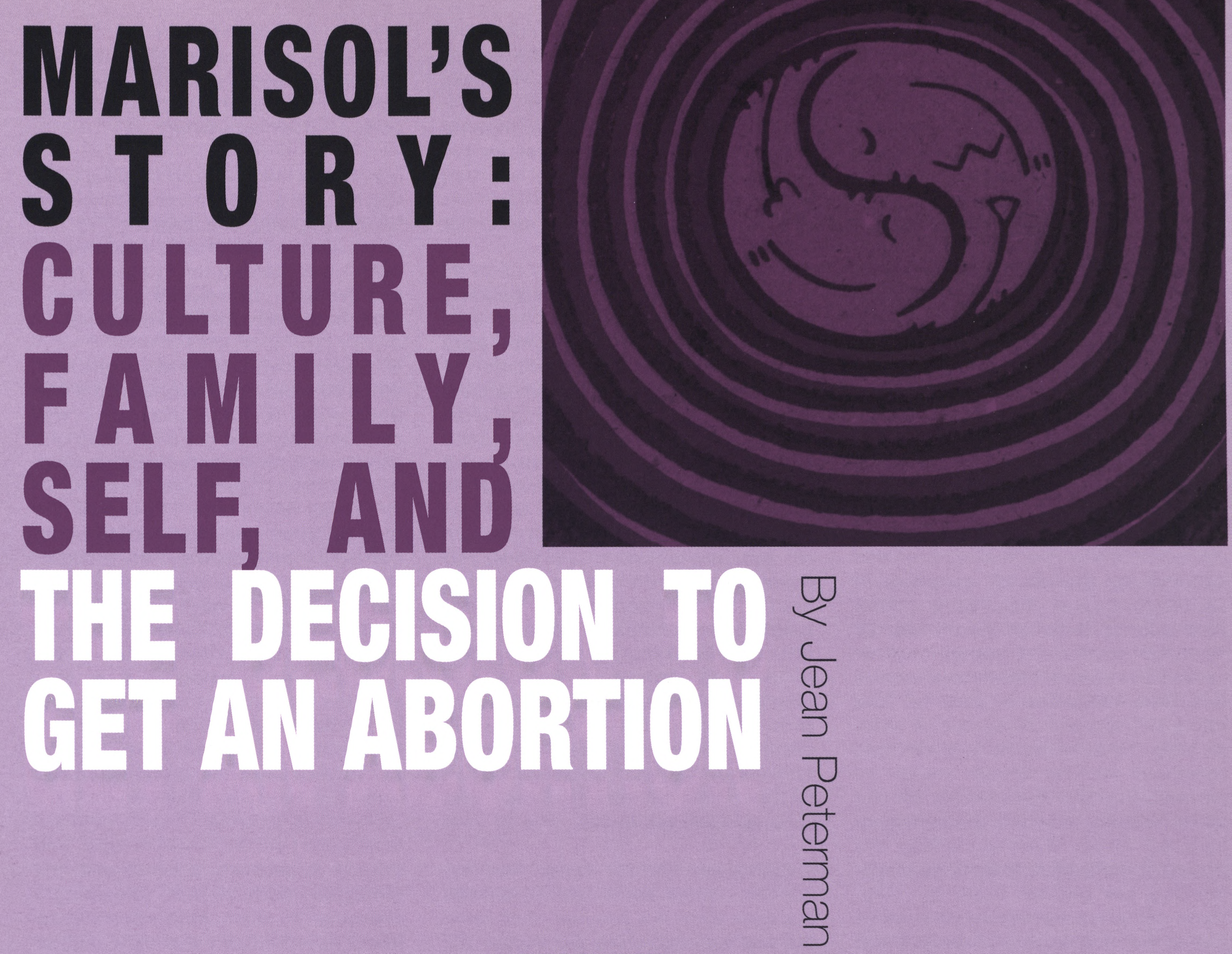

\section{ABSTRAGT}

This paper presents and analyzes the narrative of a Puerto Rican woman who aborted a pregnancy in 1992. Her story illustrates themes central to traditional Puerto Rican family life: interdependence, respect, sexual shame, and male dominance. While Marisol deeply regrets her abortion, and the need to keep it secret from her family, her experience served as a moral passage to a new way of thinking about herself and about family life. She remains committed to Puerto Rican familial interdependence, yet she favors open discussion of sexual matters within the family and respect for personal decision-making about reproductive matters. She is working to maintain an "open" relationship with her two daughters. While she rejects the gender inequality that is part of her culture, she does not reject her culture. The narrative is presented in Marisol's voice, with analytical comments by the author. 
The importance of women's stories as an alternative to male dominant cultural stories is a feature of feminist scholarship in many disciplines, including history (e.g. Lerner 1993, Personal Narratives Group 1989, Gluck and Patai 1991), literature (e.g. Rich 1979, Heilbrun 1979, 1988) and theology (e.g. Christ 1980, Erickson 1993, Say 1990), as well as sociology (Richardson 1990). In her collection of essays, Writing a Woman's Life, Carolyn Heilbrun (1988) argues that stories are essential to personal development, and that "women have been deprived of the narratives, or texts, plots, or examples, by which they might assume power over-take control of-their own lives" (p. 17). She argues that without such stories, women many not believe in their own talents, or believe that they have a right to develop them.

Arguing for the use of narratives in sociology, Laurel Richardson (1990) distinguishes between normative, or "cultural" stories and oppositional, or "collective" stories. The cultural story is told from the point of view of "the ruling interests and the normative order (p. 128). The collective story, in contrast, "displays an individual's story by narrativizing the experiences of the social category to which the individual belongs, rather than by telling the particular individual's story or by simply retelling the cultural story" (p. 128). These collective stories are alternative stories that may emerge through social movement activities or simply by a sharing of experiences. For example, stories about female self-determination and resistance to male control can provide alternatives to a patriarchal cultural story.

For many Puerto Rican women, the cultural story is about virginity, family, motherhood, and male dominance (Cofer 1990, Burgos and Diaz Perez 1986, Campbell 1984). It includes the idea that contraception and abortion are wrong (Ramirez de Arellano and Seipp 1983). Nevertheless, Puerto Rican women get abortions. Latina women, including Puerto Rican women, have abortions at a rate one and a half times as high as nonLatinas (Henshaw and Silverman 1988). This high abortion rate coupled with sexually conservative ethnic and religious traditions indicates a cultural contradiction within the Puerto Rican community. Additionally, Puerto Rican women do not share the mainstream cultural norm of personal autonomy within the family. Instead, the Puerto Rican cultural norm is one of family interdependence (Friedman 1992). Generally, this familial interdependence is a source of support. However, for the woman who needs to keep her abortion secret, not being able to share her problem with family members makes her experience especially difficult.

A Puerto Rican woman's understanding of her experience can be revealed through the way she tells her story about it. This paper is a presentation of one interview from a larger project (Peterman 1993, 1996) analyzing Puerto Rican women's experiences with abortion. Using a semi-structured interview guide, I asked each woman to reconstruct her experience with an unplanned pregnancy and her decision to get an abortion in order to determine what the abortion meant to her. I also asked about how her life had progressed since then, her plans for the future, her religious beliefs, her relationship with the man she got pregnant with, and her relationships with her parents and other family members. During the interview I asked follow up, or "probe" questions to elicit further information (Lofland and Lofland, 1984, pp. 53-62).

I interviewed Marisol twice. The first interview lasted about twenty minutes and took place in a hospital clinic while she was waiting to see the doctor. We agreed to meet the following week for lunch and a longer interview. I am presenting her story pretty much as she told it, editing for clarity, changing some identifying details, and providing her with a pseudonym. My analytical comments are in italics. They are meant to highlight 1) themes central to traditional Puerto Rican family life, such as interdependence, respect, sexual shame, and male dominance 2) the meaning of abortion for Marisol 3) abortion as a moral passage and 4) her commitment to an open discussion of sexual matters with her daughters and respect for personal decision making about reproductive matters.

\section{MARISOL'S STORY}

Before I realized that I was pregnant, my life was fine. I'm a single mother of two daughters, ages fifteen and ten. I work as a retail manager, six days a week, twelve to thirteen hours a day.
My life consists of working, coming home, making sure the girls had their dinner, get them ready for bed, and Sundays, church, and to the family, for an early afternoon dinner.

My parents live in Chicago. I grew up in Chicago, in a two parent family, with two sisters and one brother. I've left home since I was fifteen, been on my own. I was married for fourteen years, and I've been divorced for two years. I don't have many friends. I'm a loner.

The abortion was about two weeks ago. When I discovered I was pregnant it was a strange feeling because I was overjoyed. My little girl is ten years old, and I have always wanted another child.

The father of the baby, I've known him for a while, so I knew his reaction would not be joy or pleasure, even though I was hoping so. He was trying to be supportive in his way, saying that he would do whatever I wanted, support my having an abortion or having the baby, but his suggestion was to have an abortion. He said if I would have the baby, that he would help me, but the kind of help he was willing to give me was financial, which was fine, but it was emotional help that I needed.

Now, since I am, like I said, a loner, and since I respect my parents and the family so much, this is something I cannot go to them with. I don't know how. I have a fifteen year old daughter and I'm trying to raise her in the correct way, to choose, and have an open mind, but to go with this to my family, it's a 'you should have known better' kind of situation. So I had to deal with it on my own. It was very difficult. I'm thirty-one years old and it's strange, but I didn't want them to know.

My mother, to this day-my daughter turned fifteen yesterday-doesn't let me forget what I did fifteen years ago. I left home when I was fifteen to have my baby. So of course, on my daughter's birthday, she had to remind the family. So I had the abortion two weeks ago, and fifteen years ago I had the option to do that, and I chose not to. Now that I'm thirty-one and should be stable, it's not something I wanted to do, something I felt I had no choice in doing.

But ah, fifteen years ago, when I found out I was pregnant fifteen years ago, I was so overjoyed. It's so funny. I was a 
straight A student. I never expected I would have to leave school. But at the time, the father of the baby was the complete opposite of what this thirtyseven year old man was. He was seventeen, but he was willing to finish school, live a life together, and raise a family, and we did. We were married for fourteen years. We had a wonderful life and beautiful children.

Everything was picture perfect, the complete opposite of what my parents told me it would be. He got his career, he finished school, he did everything he wanted to do. And then, four years ago, when my youngest daughter had turned six, and we had our own home, a lot of things happened: we bought the home, he got laid off, I had to work full time. And Puerto Rican men have tempers. As long as they feel they're in control, they're okay. But they lose control, they become pretty violent, and he had never had that, and it started. Women in my family have been abused, threatened. That's one thing I knew I would never stand for.

Even though he had a temper, and I knew he was capable of hurting me or my children, he never did, in those fourteen years. But there was always the threat that if I spoke up as a person, that he would just knock me down, because he is the man and I am the woman. And I was right. Because when he went back to work after eight months of having him home and being so supportive because he would not look for a job, I thought I had a right to speak, and he didn't believe I did. He became abusive, and the marriage ended, because he had raped me.

The respect Marisol has for her parents and her family prevented her from openly challenging her parents' opinions or rules of behavior (Friedman 1992) by revealing her unplanned pregnancy to them. Familial interdependence is seen in the weekly family dinners and the family celebration of her daughter's fifteenth birthday. At this gathering Marisol's mother publicly reminded everyone that her daughter's birth was a matter of sexual shame for Marisol, who was a high school girl at the time. That story has a temporarily happy ending: Marisol and her boyfriend got married and had a "wonderful life and beautiful children." But things changed when the balance of power began to shift in her favor. Near the end of the marriage Marisol began to "speak up as a person" to her husband, even though "Puerto Rican men have violent tempers" and need to be in control. When her husband became abusive, the marriage ended. The divorce was stressful for Marisol (below). Nevertheless she thinks she did the right thing.

So when I found out I was pregnant it was kind of hard because it took me a long time to have a relationship with a man. I felt confident with him. It's been a while since I've been with a man, and been comfortable with a man, so his reaction was kind of a blow. Our relationship was one of friendship. He's a co-worker, and he was there for me after the divorce. For some reason, he cared. He would ask me if I was eating, and why didn't I comb my hair and take care of myself. He was helpful with my children. We had been friends for about two years, and then our relationship became sexual. We were being protective [using contraception]. We had even talked about abortion early in our relationship and I told him that I don't believe in abortion. He replied 'if you were expecting my child and you had an abortion, I would never speak to you again.' But when it happened, he was totally the opposite. The only solution ... . [tears] . . I I asked what changed his mind and he said he didn't remember that conversation!

I'm very hurt. He still comes around, but I can't cope with him right now. Instead of him supporting me, I find myself asking him what's wrong. Yesterday I told him to leave me alone. I have to deal with my own pain.

When I first knew I was pregnant I started planning what nurseries I needed. I couldn't leave my job. I was a single parent, wondering how to do it. I was going to work all the way through, no vacations, no sick leave, and take three weeks without pay. I would save up the money for the three weeks without pay. I asked nurseries about cost. It was $\$ 100-\$ 175$ per week, plus milk and diapers. Since I work thirteen hours a day, my oldest daughter would have to pick up the baby because nurseries close at $6: 00$ or $6: 30$, and then care for the baby until I got home.

About a week later, I thought "what am I doing? This is not her child, it's my baby." She couldn't join her sports anymore, because they are after school. For me to love my baby and have my baby would just stop their lives. Here I am trying to make a livelihood, trying to show her "please finish high school, please finish college. Even though I love you, and I would do it all again, I would make sure I had my education first." What am I showing her? I am showing her you can take care of a child and go to school, but I don't want that for her. That was my first realization.

And then, I'm not a healthy person. During my second pregnancy, I couldn't work. I had kidney problems, and high blood pressure. Maybe I would have health problems with this pregnancy, and be unable to work, and then what would I do?

Then, I spoke to the father. Would he help me? He told me I was a fantasizer. I was hoping, not that he would move in or anything right now, but that by the time the baby was born we would have an apartment. ( $\mathrm{He}$ is single and lives with his mother. He has a thirteen year old son.) I was hopeful, with the love I had for him, that we would be together, and he would do his part as a father, and I would not have to depend on my daughter. When I put that across to him, that's when the abortion came up. I believed the father of the child would be there, and he wasn't.

When I was fifteen it was different. I didn't know about protection. I got pregnant right away. I was delighted. I thought it was the best thing that ever happened to me. The baby would be mine, something I was going to love, something no one could take away from me. The boy was ready to marry me. We got an apartment. He was seventeen, I was fifteen. He stayed in school. I didn't go back to school. That's when I realized that love is not all that it's cut out to be, not all a bed of roses. That's the difference between then and now. I was more prepared. This time, I believed the father would be there and everything would be done the right way. I went through more hardship now, at age thirty-one, than when I was fifteen.

When I was thinking about alternatives, I realized that my [fifteen year old] daughter would be more parent than I would be. She would lose her teenage life because of something that was my doing. It would be as if she had gotten 
pregnant, which I have been trying to teach her not to do.

Each of the women in the larger (1996) study in some way integrated the decision to get an abortion into her entire life, including her personal goals and her relationships. Each one considered, briefly or at length, what her life would be like if she did or did not get the abortion. Building on Barbara Katz Rothman's (1989) idea that an abortion takes its meaning from the woman who is pregnant, I analyzed each of the narratives for patterns of meaning. Throughout the interview process, four categories emerged that characterize the meaning of abortion for individual women: "keeping on being who I was," preserving life or health, coping with physical or emotional abandonment, and resisting or escaping male control. For some women the abortion had more than one meaning. Marisol is one of those women. For her, the abortion was a way of coping with her partner's emotional abandonment when she felt she needed him most. Additionally, she did not want either of her daughters to repeat her own life pattern. If she had the baby her oldest daughter "would lose her teenage life" to parental responsibilities, as though she herself had given birth. Marisol's abortion allowed her to maintain her employment and allowed her daughters to continue their education without the responsibilities of early parenthood.

When I was laying there, when the abortion was happening, I lost a part of myself that I will never get back. I had a hard time looking at myself in the mirror afterward. I have a hard time talking to my daughters, even though they don't know. It's something I can't deal with.

I didn't want to have a sexual encounter with him. I let my emotions take over. He led me to believe that if anything would happen, he would be there for me, and he wasn't. He also led me to believe that if I were ever to become pregnant there would be no other answer than for us to raise our child. So with all this I've learned a powerful lesson. I learned that everyone is not what they say.

I used to think of myself as a good person. I used to think that a child is a blessing. I took all that away from myself. I had to tell myself that I didn't have any choice. All I kept saying through the whole process was that I hope that God can forgive me, so that I can forgive myself, for what I did. [Do you think God can?] No. ... [tears]

My decision to get an abortion was much harder than any other in my life. Nothing has been as difficult, and I don't think anything ever will be. It was much harder than my decision to get a divorce, and much harder than when I was pregnant with my second child. I had serious health problems then, and the doctor told my husband to choose between my life and the baby's life, and the doctor also asked me. I said 'I can't choose, I leave it in God's hands.' This [abortion] was a decision I had to make. I couldn't leave it in God's hands.

I remember the day I got the abortion, waking up, going back to sleep, not wanting to wake up. I had to take my daughter to school. The father of the baby was taking me. He insisted he wanted to be there for me. He took me to the abortion clinic. I couldn't stop crying, through the waiting, the paperwork, the counseling. My counselor asked "is this what you want to do?" [no]. "Then why are you here?" [I don't know, it's something I have to do, I don't have a choice.] I kept saying it over and over, and then they brought my friend, the father, in. I remember when he walked in. It was my last attempt for him to say "I'll help you, I'II be there." I don't know what I expected. I kept saying, "I can't go through with it," hoping he would offer to help me. I was angry that I couldn't have my child. I loved it. I talked and screamed. He just watched and didn't say anything. The counselor listened as I told her about my daughters and everything and wrote everything down. Finally, she said "is it fair, if you want the baby, to lose your children? You are telling me that you are the only parent, the sole support. Would you want your daughter to be pregnant right now, to have a child? [No.] That's what you're telling me you're going to do. It's very difficult. I believe that you want the baby, but I believe that you, at this time, cannot have the baby." I cried. She was right. She was telling me what I was telling her. Then she asked, "Are you angry?" [Yes.] "Who are you angry at?" and I said "Him, he promised he would be here, and he's not." She left the room [so we could be alone]. After all this he said, "don't do it." I knew this was insincere. He had encouraged me to have the abortion, and had sat there [at the counseling session] for hours, saying nothing. He never asked me how I felt, he never asked me anything.

The worst part was laying on the table, asking God to forgive me, asking the baby to forgive me. I was feeling ugly. After it was over he took me home and left me there. I felt hatred, not for him, but for myself. That's when I really started disliking myself. I try to find ways to like myself. My sister has a little child. I can't even look at children. I can't even watch TV.

If he were here right now, I would tell him off, because it's not fair. It's like nothing ever happened, it never existed. I'm so angry at him. Our relationship is over. It's hard for me. Besides speaking to you, the only other person who knows about this is him, but he is not really there for me. I would like to be able to talk to my Mom about this, but I can't. If I told her about the abortion she'd never speak to me again.

I never want my daughters to go through this [not being able to talk to me]. I think my daughters could come to me for advice and information. We're pretty open with each other. Actually, my fifteen year old daughter recently approached me and said "I haven't had sex yet but it might happen soon, so what would you tell me?" I told her to make sure that you are ready, and when and if you are going to, please use a condom. She said "is that the safest way?" and I said "nothing is one hundred per cent safe; I would prefer that you were older, but you are able to make decisions." [There aren't many parents who could say that to their child. You should feel proud.] I do. I am proud.

I didn't think much about abortion, but I was totally against it. Both of my parents are totally against it. Having an abortion has made me even more totally against it, because now it's more emotional. Everyone talks about right or wrong. Nobody talks about the emotional part. I don't think my abortion was the "right" decision, but it was maybe the best decision at the time, but the right decision? It was best in terms of the situation, yes, but as right or wrong?

If a friend were to come to me for advice about an unexpected pregnancy, I would tell her to make sure its exactly 
what she wants, whatever decision she is making is what she really wants, not because it's the right thing or the wrong thing, or the best thing. This is what she, personally, wants to do -have the baby, have the abortion, give the baby up. She's the one that's got to live with it.

Addelson's (1991) notion of "moral passages" provides a useful way to think about how major life experiences such as abortion are integrated into one's life. Addelson explains that morality emerges out of people's interactions, and emphasizes the importance of placing these experiences within the context of women's lives, and within the context of social support, or lack of support, for meaningful lives. As women make such passages, they can either realign themselves with conventional thinking or create a new definition of themselves and their behavior.

Toward the end of each interview, I asked each woman if she thought she had made the right decision about her pregnancy. Sixteen women answered with an uneqivocal yes, three (including Marisol) are ambivalent, and one thinks abortion should be outlawed. For some women the abortion remains a shameful secret. For others it is part of a process of empowerment. For a few women, including Marisol, it is both.

What the abortion meant to each woman is almost perfectly correlated with whether or not she has redefined abortion from a "wrong" or a "sin" to a more positive definition of abortion as something a woman might need in order to live a meaningful life. Women who obtained abortions as a way of "keeping on being who they were" or as a way of resisting male control have redefined abortion in this way, while those for whom the abortion was a way of coping with male abandonment have retained a definition of abortion as wrong, or a sin that God will forgive. Another variable correlated almost as closely as the meaning of abortion for the women's life is whether or not the respondent had any support for her decision. Those women who knew someone who had gotten an abortion, or received support for their own decision, were more likely than the others to redefine abortion positively.

Marisol maintains a definition of abortion as shameful. At the time of our interview she had told no one other than her partner, relevant medical personnel and me about her abortion. Nevertheless she recognized that she had to make a decision (rather than leaving it up to God) and her advice to a friend with an unplanned pregnancy would be to make sure to do what she really wants. Marisol could not accept her abortion as the "right" decision but described it as the "best decision at the time ... in terms of the situation."

[After discussing Marisol's abortion I asked her about her background and personal beliefs, and how her beliefs might have changed.] I was brought up Catholic and I am Catholic now. I was born in Chicago and have lived in Humboldt Park and Logan Square. Now I live in the suburbs. I have aunts and uncles in Puerto Rico and used to go there every year, before my grandparents died. I associate more with Puerto Ricans than Anglos, and my primary language is Spanish. My daughters' primary language is English.

I was brought up to believe that the man comes first. He is the sole breadwinner and the woman should stay home. She doesn't need an education or anything. When I got married I wanted to return to school but my husband said no. I insisted that he finish, and he did. I don't agree that the man comes first and the woman doesn't need an education anymore. What about death or divorce? The family says they will be there for you but that is not true. They can help some but not enough. A woman needs an education. I have worked since I was twelve years old. I don't think my working hurts my daughters. I make our time together count. Right now we don't have much [in material things] but they say, "Mom, one day we will." I'm proud of my daughters. They come first, and they know that. My opinions about these things have changed because of my own experiences.

It's sad to say how I feel about the Catholic religion. I want help and they can't give it. Their opposition to abortion makes me feel worse. It's not enough that I condemn myself. I know they will condemn me. He [the father] asked me if I had been to the priest. All I did was laugh. I would never go to a priest about this. I've stabbed myself enough. How can I have someone else stab me some more? That's why, the Catholic religion, I'm angry at them. I understand their beliefs about "life" because I loved my baby. I can understand their part in it. It's [abortion] not an easy step. And what I have seen and heard them say and do in the masses is that we can just get rid of it [abortion] like this. And that's not true. It's not. The way they have brought me up, it's not a place I can go for comfort [but] I need for God to forgive me.

If he [partner] knew he wouldn't want a child, he should have been honest and said, "I know you can't take the pill [for medical reasons], and we have to do something [use a condom]," and not tell me, when I said I didn't have anything [a condom], "Don't worry, we love each other, and everything will be fine." He knew I was totally against abortion, yet that was the first thing he came up with. I blame myself though. I trusted him.

My religion is very important to me. So are my children. They are my life. I have never thought about myself as a person worth anything because I have always tried to please others and make them happy. Now I know I have to take care of myself, and like myself, for others to live with me. No matter how many others say you are a good person, if you don't like yourself. ... It's even harder now. The more I look at my daughters, the less I want them to be like me. I want them to be strong. I want them to make decisions, and think before they make decisions. I want them to know that there are choices. I want them to feel safe but yet know that it's an unsafe world.

My family is very religious, and very traditional. Puerto Rican children raised in a traditional way would never dare bring up "abortion" in conversation. Someone from the older generation has to bring it up first. My family has talked about abortion. Most of them think women who get abortions have no morals, no beliefs, no respect, and no love.

I could never go to a family member to talk about my abortion. You know you can't talk about it. If I were to tell my brother, or one of my sisters, the whole family would know. There are no secrets.

You don't want to "test" your family. You could be made an outcast, so you do it to yourself, become an outcast in your mind. You do it to yourself, so that way, you don't dislike them, you can still 
love them. The pain of being outcast by someone you love is so severe. If family can't love you, who can? So you outcast yourself. You take yourself away from the family, don't communicate, see them less, so they don't find out. If you stay around the family, one day, you will break down, and then, you might get the support, but more and more, you believe that you won't, so you outcast yourself, and the sad part is, they don't care. You can say, "I'm too busy," and they will go back and won't question if anything is wrong. Family gatherings are "gossip city." Everyone talks about their lives. If you're at a family gathering it means your life is open to everybody. That's how Puerto Ricans are. If you don't talk about your life, something is wrong with you.

A collective (oppositional) story comes into being when individual stories about common experiences are shared (Richardson 1990). The idea that women are entitled to make choices that enable them to live meaningful, self-determined lives stands in opposition to the patriarchal cultural story. Although Marisol is not about to share her abortion experience with anyone she does want to share what the experience has taught her. Her account portrays the pain of isolation from family members. Even though she is thirty-one years old she regrets that she cannot share her experience with her mother. Marisol does not want her daughters to feel this way about her. She also does not want them to be ignorant about sexual matters. According to traditional Puerto Rican family norms of respect children do not bring up subjects like "abortion" in conversation. Someone from the older generation has to bring it up first. Marisol is taking on this responsibility and is striving to create an "open" relationship with her daughters. She wants them to "make decisions, and think before they make decisions [and] know that there are choices, [and] feel safe but yet know that it's an unsafe world."

My mom doesn't agree with me about how I am raising my children. After the divorce, I was living with my parents. When I moved away, she was totally against it. She wondered why I was moving so far away [to the suburbs], why I was taking my daughters away from them, and why did I put them in a certain school. Actually, she didn't ask "why?", she said "don't." It took her a year to come and say to me, "You did the right thing. "I'm an adult, and this is the first time she has ever admitted she was wrong. For a Puerto Rican mother-I was amazed. If they are wrong and they know it, they still don't admit it. So I hugged her, for the third time in my life.

\section{DISHUBS10N}

During our interview I turned off the tape recorder three times because Marisol had begun to cry. Each time, she insisted that we continue, saying that the interview was helpful to her and that I was the only person she was able to talk to about her abortion. One reason for her tears might be that her abortion was only two weeks prior to the interview and her feelings were still raw. Another reason is that Marisol values her family, her culture, familial interdependence, and her Catholic faith. She is deeply disturbed that her church and her family of origin cannot deal with her pain in any realistic or helpful way. Marisol's narrative is an example of how difficult it is for some Puerto Rican women to retain a definition of themselves as "good" despite having violated cultural norms.

Mainstream theories of ethnicity and culture generally do not critically examine what counts as ethnic culture and to what effect (Das Gupta 1997). Markers of ethnicity are often cultural variants of patriarchy. In her interviews with Indian women Monisha Das Gupta found that the question, "What is Indian about you?" elicited stories of anguish and conflicts about gender roles that echo Marisol's. She states that her respondents' accounts allowed her to recognize the gendered power relationships embedded in signifiers to ethnic identity.

Marisol understands that Puerto Rican culture is patriarchal. She explained that "Puerto Rican men have tempers. As long as they feel they're in control, they're okay". She also said that she was "brought up to believe that the man comes first." Marisol is not raising her daughters with this attitude however. She wants them to be "strong" and to "know that they have choices."

Culture is not unchanging and it doesn't have to be accepted or rejected as a total package. Marisol's narrative provides an example of a Puerto Rican woman who is trying to figure out how to continue to embrace her family and her culture while rejecting the gender inequality within it.

\section{REEERENGES}

Addelson, Kathryn Pyne 1991. Impure Thoughts: Essays on Philosophy, Feminism, and Ethics. Philadelphia: Temple University Press.

Burgos, Nilsa M. and Yolanda I. Diaz Perez 1986. "An Exploration of Human Sexuality in the Puerto Rican Culture," Journal of Social Work and Human Sexuality, Vol. 4 pp. 135150.

Campbell, Anne 1984. The Girls in the Gang: A Report From New York City. New York: Basil Blackwell.

Christ, Carol P. 1980. Diving Deep and Surfacing: Women Writers on a Spiritual Quest. Boston: Beacon Press.

Cofer, Judith Ortiz 1990. Silent Dancing: A Partial Remembrance of a Puerto Rican Childhood. Houston: Arte Publico Press.

Das Gupta, Monisha 1997. "What is Indian about You?": A Gendered, Transnational Approach to Ethnicity. Gender and Society, vol. 11 No. 5 pp. 572-596.

Erickson, Victoria Lee 1993. Where Silence Speaks: Feminism, Social Theory and Religion. Minneapolis: Fortress Press.

Friedman, Jennifer 1992. "Pathways to Adulthood for Latina and White Adolescents and the Role of the Family, Latino Studies Journal, Vol. 3 No. 1 pp. 9-30.

Gluck, Sherna Berger and Daphne Patai 1991. Practice of Oral History. New York and London: Routledge.

Heilbrun, Carolyn G. 1979. Reinventing Womanhood. New York: W. W. Norton.

1988. Writing a Woman's Life. New York: Ballantine Books.

Henshaw, Stanley K. and Jane Silverman 1988. "The Characteristics and Prior Contraceptive Use of U.S. Abortion Patients," Family Planning Perspectives, Vol. 21, No. 4. 
Lerner, Gerda 1993. The Creation of Feminist Consciousness: From the Middle Ages to Eighteen-seventy. New York: Oxforn University Press.

Lofland, John and Lyn H. Lofland 1984. Analyzing Social Settings: A Guide to Qualitative Observation and Analysis. Belmont, California: Wadsworth Publishing Co.

Peterman, Jean 1993. "Puerto Rican Women Deciding to Get an Abortion: Beginning a Collective Story," in Latino Studies Journal, Special Issue on Latina Women, Vol. 4 No. 3 pp. 44-59.

1996. Telling Their Stories: Puerto Rican Women and Abortion. Boulder: Westview Press.

Personal Narratives Group 1989. Interpreting Women's Lives: Feminist Theory and Personal Narratives. Bloomington and Indianapolis: Indiana University Press.

Ramirez de Arellano, Annett B. and Conrad Seipp 1983. Colonialism, Catholocism, and Contraception: A history of Birth Control in Puerto Rico. Chapel Hill: Univsersity of North Carolina Press.

Richardson, Laurel 1990. "Narrative and Sociology," Journal of Contemporary Ethnography, Vol. 19 No. 1 pp. 116-135.

Rich, Adrienne 1979. On Lies, Secrets, and Slience: Selected Prose 1966-1978. New York: W.W. Norton and Co.

The Labyrinth of Birth Through The Gate From your Inner Word Out of your Darkness, Born Again. You in Me.

\section{El Laberinto Del Nacimiento Por El Portón \\ De tu Mundo Interior \\ Brotando De Tu Oscuridad, Renazco. Renaces En Mi.}

Angelika Bauer

Rothman, Barbara Katz 1989. Recreating Motherhood: Ideology and Technology in a Patriarchal Society. New York: W. W. Norton \& Co.

Say, Elizabeth 1990. Evidence on Her Own Behalf: Women's Narratives as Theological Voice. Savage Md: Rowman and Littlefield. 